\title{
EUROPEAN VISION AND ABORIGINAL ART: BLINDNESS AND INSIGHT IN THE WORK OF BERNARD SMITH
}

\author{
Susan Lowish
}

\begin{abstract}
Presently, Australian art histories do not adequately account for the existence of Aboriginal art. They tend to re-present and accentuate European constructions of difference, otherness and isolation, rather than explore sites of intersection or look for similarities. A radical readjustment of perspective is needed in order to address this imbalance. This article suggests that although Smith's writing on Aboriginal art does not provide a suitable basis for this revision, his evaluation of European visual culture during the early exploration of the Pacific might form a useful starting point for an art historical reassessment of the relationship between Aboriginal and Australian art.
\end{abstract}

Bernard Smith is widely regarded as Australia's most respected art historian and has been described as 'a passionate intellectual with a commitment to the causes of indigenous people and social justice' (Spencer and Wright, 2000: 15). His 1980 Boyer Lecture 'The Spectre of Truganini' is one expression of this commitment, and his continued financial backing of the Kate Challis RAKA Award, ${ }^{1}$ one of Australia's most valuable national awards for Indigenous creative arts, is another. Given this ongoing public support of Indigenous Australians, it is surprising that Smith has barely mentioned their art in his many publications. Why is Smith so reticent to engage directly with Aboriginal art in his writing of Australian art histories? What might this reticence suggest about the overall status of Aboriginal art in relation to Australian art history, especially given Smith's influence in the field? This article focuses upon Smith's publications, in comparison with other works on Australian art, and considers the excuses for and impact of the exclusion of Aboriginal art from Australian art history.

In his Boyer Lecture, Smith notes that 'the crucial challenge to [Australian] culture is to come to terms with the continuing Aboriginal presence' (Smith, 1981: 44). This challenge has never been more strongly felt in the discipline of art history than it is today. Perhaps due to embarrassment caused by its long absence or a new found interest in reconciling histories, there is an urgency to add studies of Indigenous Australian art to university art history programmes across the country. A number of recent publications also deal with the incorporation of Aboriginal art into narratives of Australian art (Butler, 2002; Sayers, 2001; T. Smith, 2002). However, if the aim of these courses and publications is to situate Aboriginal art within Australian art history, even in the most general sense, they have not been very successful. Much of what is relevant to the discipline of art history does not correspond easily to the study of Aboriginal art, just as much that is vital to understanding the complexity of Aboriginal art, let alone the various cultures in which the work is 
produced, lies outside the reach of art history.

Smith writes briefly about the possibility of cultural convergence in the final section of his Boyer Lecture and expands upon it in two essays, both published in Smith (1988). However, it is not clear that this is an accurate way of describing Aboriginal art. Borrowing the term from the Australian poet Les Murray, Smith describes cultural convergence as a meeting of 'the traditional Aboriginal culture' and 'the white culture' (Smith, 1988: 300), 'the interaction, on one soil, of two cultures of immense antiquity' (Smith, 1988: 295). There are obvious problems with this. What is the Aboriginal culture, the white culture? If both are ancient, why is only one of them 'traditional'? What is 'traditional' in Aboriginal cultures, and who is Smith to judge? It is important to note that there is a marked difference between our understanding of Indigenous cultures and this thing we call 'Aboriginal art', and it is probably for good reason that Smith has rarely commented on Aboriginal art and claims never to have assessed it (Smith, 2001b). Nevertheless, the notable absence of Aboriginal art from Smith's art historical writing can be interpreted as an assessment in itself.

\section{PLACE, TASTE AND TRADITION}

Although he had published articles from as early as 1938 - most of which advocated for a wider public appreciation of visual art - Smith's Place, Taste and Tradition (1945), based on a series of lectures, is widely considered his first major attempt at recording an Australian art history. Praised over William Moore's earlier Story of Australian Art (1934), Place, Taste and Tradition is where 'Smith had established some new lines of historical thinking about Australian culture and had argued for the politics of art' (Beilharz, 1997: 43). Smith's book unselfconsciously takes as its main concern the relation between the arts in Australia and the European tendencies upon which they draw (Smith, 1945: 14). The work has been described as a politically charged polemic (Burn et al., 1988: 49) and remains highly influential in the way it structures the main stylistic epochs of art in Australia.

In Place, Taste and Tradition, Smith makes few references to Indigenous Australians. Their art is given little more than passing consideration and its difference from Australian art is always noted. For example, in his introduction he writes that 'the aborigines, who possessed a fine art of their own, could not be assimilated into the colonial population' (Smith, 1945: 18). Of course, his use of the past tense is problematic, but, to be fair, Smith is not focusing on Aboriginal art here but seeking to assess the influences on and traditions of settler Australians prior to 1945. It is little wonder that when he writes of 'Early Australian Primitives', in this work, he is referring specifically to naive artists like William Bradley, James Wallis, and Robert Dowling, not Indigenous artists, such as William Barak and Tommy McRae. In the 1940s, Indigenous artists were considered primitive artists of a distinctly different kind to artists of European descent. ${ }^{2}$ Subsequent publications on Australia's primitive painters have done little to elide this difference (Lehmann, 1977). 
Sometimes, confusion arises because the different meanings of the term primitive, as it is used in art history, become intertwined. There are at least three distinct meanings. Firstly, as a largely archaic term, 'primitive' was used to refer to peoples outside the 'great centres of civilisation', reflecting the mistaken 'evolutionist' belief that some cultures are less 'advanced' than others. Secondly, the term applies to the early phases within the historical development of painting or sculpture specifically in European countries, such as pre-Renaissance Italian art. Thirdly, 'primitive' is a term used to describe artists with no formal training or whose works are highly idiosyncratic in a way that is outside the academic, traditional or even avant-garde manner (Osbourne, 1970: 925). While many contemporary Indigenous artists' work could be described as 'primitive' in the third sense, the term is not used for fear of reprisal. Due to these negative connotations, untutored Aboriginal artists are not considered the same as their European counterparts.

Smith's most sustained reference to Aboriginal art in Place, Taste and Tradition occurs in relation to his strong critique of the Jindyworobacks - a cultural movement of the early 20th century which aimed to establish distinctively Australian literary forms. In this early publication, Smith did not approve of their efforts, describing the movement as 'nothing more than an invocation to go back to a state of nature' or worse 'to return to yams and witchetty grubs, to the spear and the churinga and, finally, to Alcheringa' (Smith, 1945: 166). He describes the work of Margaret Preston, a South Australian artist who adapted the designs and colours of Aboriginal art, as a phase of primitivism and, as such, not a 'basis for a truly Australian art' (Smith, 1945: 189). Smith's desire to define Australian art is his over-riding concern here; he argues for it with a passion. 'A national trend in Australian art should be sought for, not in the hopeless endeavour to create an artform peculiar to this continent - as aboriginal art was - but an art the nature of which will grow from the features of a changing Australian society' (Smith, 1945: 21). Again, he refers to Aboriginal art in the past tense and, even though he was interested to see what might develop from using the art of Indigenous Australians (Smith, 1945: 189), in 1945, it did not form part of Smith's vision of Australian art. ${ }^{3}$

From the vantage point of the early 21st century, Smith's views on Aboriginal art seem outdated. Yet, to criticize his attitudes and beliefs on this basis is neither productive nor appropriate. As Smith himself has remarked, 'even the most practised critics frequently express nothing more than the prejudices of their times' (Smith, 1976: 56). Smith does more than this. He is an astute social commentator whose work has established major trends in Australian art history; one of them maintains Aboriginal art's difference from the rest of Australian art. As such, Smith's work has proved a powerful precedent for the exclusionism to which current revisions are in part a reaction. An example of Smith's legacy can be seen in the work of art critic and lecturer Christopher Allen. In the 224 pages of Art in Australia: From Colonization to Postmodernism (1997), he mentions 'Aboriginal art' twice. The first instance is in relation to the Australian painter Margaret Preston, for whom 'Aboriginal art offered the possibility of a reconciliation between modernism and the nationalist landscape tradition' (Allen, 1997: 106). The second instance is in the final paragraphs, 
where Allen describes the present popularity of desert acrylic painting both in Australia and internationally as 'a new authenticity' seized upon by a desperate art world (p. 214).

However influential Smith's work has become, the exclusionist perspective is not the only approach historians of Australian art have taken in relation to Aboriginal art. Other studies, contemporaneous with his, have included Aboriginal art in their trajectories. William Moore, whose work Smith greatly admired, began his epic Story of Australian Art (1934) with early accounts of rock painting and engraving and various interpretations of them, remarking on the success of the first exhibition of Australian Aboriginal art held in 1929 (Moore, 1934: 1-5). The reference is a brief but important acceptance of Aboriginal art as part of Australia's art history. Moore situates it as a first step in the history of art in Australia but makes no further mention of it. This is perhaps more problematic than leaving it out altogether for it implies that Aboriginal art is over and gone, suitable only as a basic starting block from which the more 'advanced' European style has taken over. In this way, Moore treats Aboriginal art as chronologically and culturally 'primitive'. We are left pondering the advantages of this approach, but is Smith's treatment of Aboriginal art, as radically different, any better?

When the individual lectures that constitute Place, Taste and Tradition were being written, one of a handful of Indigenous artists to have any kind of public profile was Albert (Elea) Namatjira. Smith worked on the professional staff at the Art Gallery of New South Wales from 1944 to 1954. He recalls, in an interview with Sylvia Kleinert, that 'he could not accept Namatjira's paintings because they seemed to fall within the conservative landscape tradition. Yet at the same time he felt ambivalent and guilty about his failure to applaud Namatjira's achievements' (Kleinert, 1992: 227). Kleinert notes that there was a public outcry in 1954 when it was discovered that the Art Gallery of New South Wales did not own a painting by Namatjira. Subsequent revisions of his work and life have seen his achievements honoured from a number of different perspectives. The major Australian museums and art galleries are currently making a concerted effort to realize the importance of Namatjira not only to the history and development of Indigenous art and politics but also to Australian art as a whole.

In the 1980s, Smith was highly critical of the attitude 'that had prevailed for over a century and had deterred curators from including Aboriginal art in Australian collections' (Smith, 1988: 5). This statement is somewhat ironic give that Smith seems to have been complicit in endorsing this same attitude when working for the art gallery in the 1940s and 1950s. In the first edition of Australian Painting, he did not celebrate Namatjira's work as Aboriginal art but described it as following Rex Battarbee in the tradition established by Hans Heysen (Smith, 1962: 115). Smith's rejection of the dominant trend of landscape painting in Australian art has been critiqued (Burn et al., 1988: 65). Perhaps this bias added to Smith's blindness toward art by Indigenous Australians, given that so much of their art is about their country. For whatever reason, Smith's lack of insight into Aboriginal art from the 1940s continued. 


\section{AUSTRALIAN PAINTING}

Many of the stylistic categories established in Place, Taste and Tradition were developed and reinforced in Smith's iconic work of Australian art history, Australian Painting 1788-2000 (2001a). Highly influential in its interpretive framework, this book unselfconsciously repeats Smith's reading of the dependency of Australian art on overseas sources. Currently in its fourth edition, Australian Painting is widely regarded as a comprehensive introduction to the subject, with the publicity blurb confidently claiming coverage of all aspects of the field. With each successive edition, chapters have been added, the third and fourth editions featuring work by Terry Smith and Christopher Heathcote respectively. Both these writers have included Aboriginal art as part of Australian art, with Terry adding a chapter titled 'From the Desert: Aboriginal Painting 1970-90' and Heathcote naming a section 'Tribal Painting' in his chapter 'An Embattled Medium 1991-2000'. Although there is not the space to analyse them here, both efforts fall short of including Aboriginal art in any equitable fashion. They continue to emphasize its difference from the rest of Australian art and highlight the paucity of understanding of Aboriginal painting by Australia's leading art historians in the present day.

Until 1991, Australian Painting contained only one reference to Aboriginal art: 'The Aboriginal art of Australia, it might well be argued, is an art which has evolved in isolation from the rest of world art' (Smith, 1962: 333). For the third edition, Bernard invited Terry Smith (no relation), then Power Professor of Fine Art, University of Sydney, to write three additional chapters including the previously mentioned one on Aboriginal painting. When he notes that 'Aboriginal painting does not conform to the logic of historical development that we have been tracing in white Australian art' (T. Smith, 1991: 495), Terry echoes Bernard's way of thinking about Aboriginal art as being separate from settler Australian art. Indeed, herein lies the problem. The logic of the arguments in Place, Taste and Tradition and in Australian Painting excludes art by Indigenous Australians by virtue of the fact that it is constructed around the model of centre/periphery. As Bernard writes in Place, Taste and Tradition, 'this study is largely concerned with the mutations which have occurred in styles and fashions originating overseas as they have been assimilated into conditions . .. existing in Australia' (Smith, 1945: 21). Smith is not concerned with Aboriginal art because it is outside the margins. His 'marginalised other' already exists as Australian painting itself.

In the same year the second edition of Australian Painting was released, the surrealist painter James Gleeson published his Australian Painters (1971). Part of the Australian Painting Studio Series, Gleeson's book, like Moore's, opens with an account of Aboriginal art. The section on colonial painters begins with a discussion of the lack of recognition Aboriginal art has received. Unlike Smith, Gleeson does not accentuate Aboriginal art's difference from Australian art as the reason for its exclusion. Instead, he points to an inability on the part of settler Australians to recognize Aboriginal art as art. In particular, he states that, from the time of first settlement, 'another century was to pass before it became possible for the European mind to accept such things as an alternative but genuine form of art' (Gleeson, 1971: 15). In this statement, he defines Australia's art history as characterized by the non-recognition and non-acceptance of Aboriginal 
art. Despite this, Gleeson's commentary rapidly declines into a form of cultural primitivism. He writes: 'Theirs is an essentially a simple art, with the profound simplicity of a primitive mysticism; yet its forms are sophisticated because they have been developed during centuries of unchanging tradition' (p. 23). He also writes of not being able to enter into works by Aboriginal artists as 'true participants', without close and prolonged study (p. 15). Despite some brief flashes of inspiration, he still refers to Aboriginal society as a 'primitive civilisation' and, like Moore, relegates his assessment of their art to the first few pages of his book.

Smith barely mentions Aboriginal art, only doing so to critique certain nationalistic movements in Australia's art history or to state how different it is from the rest of Australian art. Moore and Gleeson have made token efforts at inclusion. Between them, there is little in Australian art writing that would inspire histories that account for both Indigenous and settler Australian art. Perhaps art historians should look to other disciplines, such as anthropology, Australian history, legal and environmental studies, in combination with protocols established by various Indigenous groups, in order to fill the gaps or find suitable models for negotiating the complex demands of engagement. One thing is certain though; Aboriginal art is here to stay. It requires more attention from art historians and we need help in negotiating ways to constructively engage with this work, the artists and the people who sustain the industry. As such an influential figure in Australian art history, is there any way that the writings of Bernard Smith might help art historians, critics, curators and practising artists engage with Aboriginal art? Can a model be drawn from his work on other aspects of Australia's visual history?

Recently, Smith explained his reticence to tackle the subject of Aboriginal art in terms of a lack of knowledge. For him, the problems of meaning Aboriginal art presents are best addressed by Aboriginal people themselves, or by perceptive anthropologists, such as Ronald and Catherine Berndt (Smith, 2000: 12). To a certain extent, he has a point. The knowledge provided by the artists, members of their communities, often via translators, anthropologists, linguists, sociologists, or the dedicated art workers who have helped foster and sustain the industry since its beginnings, obviously add vital dimensions to the study of Aboriginal art and help to enrich the meaning of artworks. Nevertheless, it is important that high profile art historians, like Smith, address these problems both in relation to other Australian art and international art. Too often and for too long, ignorance has been an excuse for a lack of engagement with Aboriginal art.

Thankfully, the drought has started to break and some art historians are venturing to write about Aboriginal art. Of the attempts presently being undertaken, Smith has made the following remarks:

The recent acceptance of Aboriginal Art as a mode of Australian Art does not alter its basic narrative framework. What is now being done by scholarly revisionists of our art history, and rightly, is the successive recognition and incorporation of Aboriginal Art as art in the special sense within the Australian tradition during its Colonial, Impressionist and Contemporary manifestations. (Smith, 2000: 4, emphasis in original) 
From this passage, it is clear that Smith's acceptance of Aboriginal art is predicated upon remaining within the structure that he has worked hard to establish in his previous publications. He is pleased with this current trend of revisionism but warns us of "the fatal temptation . . . to anachronise history in a futile attempt to redeem it. To "Aboriginalise" the Australian Art tradition prior to the emergence of the art of Albert Namatjira, to treat it as art in the special sense when it was in fact regarded only as an integral part of Aboriginal culture both by Aboriginal people and others' (Smith, 2000: 4). Elsewhere, Smith has stated that 'what is now called aboriginal art only became art in the special sense after Geoffrey Bardon's intervention at Papunya in the early 1970s, prior to that it was largely an integral part of the ritual process' (Smith, 2001b: n.p.). The importance Smith places on Bardon's role in what has subsequently been termed 'the Aboriginal art revolution' is evident most clearly in his short article titled 'How Art Should Be Taught' (Smith, 1991).

By qualifying what does and does not count as art, Smith echoes his old colleague Donald Brook. Their exchange, in the pages of Meanjin (1987-8), revolves around this very issue. Brook argues for a distinction between 'art properly so-called' and 'art conventionally so-called' (Brook, 1988: 165), Smith responds by stating that Brook is 'taking words too seriously' and criticizes Brook's 'reluctance to accept tribal artefacts as art' (Smith, 1988: 6, 10). In his recent tome, Modernism's History (1998), Smith makes a similar distinction between 'art in the special sense', which is fine art (p. 17), and 'art in the general sense', which is craft and industrial art (p. 41). In both these qualifications, Smith and Brook are making distinctions based upon the values of 'western appraisers'. In doing so, Aboriginal art is effectively 'othered', having little impact on the established canon of art or the methods of perceiving it.

There are dangers in reassessing art history but it is not clear that treating Aboriginal art as 'art' causes them. Historians select events from the past in order to construct their own narratives. Since the time of first contact, there have been accounts that praise the artistic value of Indigenous imagery; these have largely been ignored by art historians. Smith has argued, in defence of art history, that the kinds of valuing intrinsic to writing history are subjective. Without resorting to creating further divisions within art, what is required is a broadening of perspectives. In Place, Taste, and Tradition, Smith writes of 'the habit of vision' by which early colonists viewed the Australian landscape; these colonists had a distinctly European vision of Aboriginal art. Smith also writes of distortion of vision, 'found most strongly in the depiction of objects about which visual habits or mental preconceptions had established an image that possessed considerable resistance to change' (Smith, 1945: 19-20). Is not a similar distortion possible in the perception of what now constitutes Aboriginal art? Sociologist Peter Beilharz claims that 'Smith is best read as a social theorist', implying that his greater legacy is to disciplines other than art history. He adds that 'his is a project of profound insight, not the least of all into what hitherto has been called "national character", matters to do with cultures local and imperial, central and peripheral' (Beilharz, 1997: xii). Certainly, Smith's works European Vision and the South Pacific (1960) and Imagining the Pacific (1992) demonstrate his skill at producing a critique of the established norms of art history and the use of art by scientists and explorers. In both these works, Smith identifies different 
aesthetic tastes that dominated European perceptions in different epochs. He uses them to define the limits and constraints of European understanding of other lands, peoples and cultures. How disappointing then that Smith's insight does not extend to his perception of Aboriginal art. The literary critic Paul de Man best explains this anomaly:

The insight exists only for a reader in the privileged position of being able to observe the blindness as a phenomenon in its own right - the question of his own blindness being one which he is by definition incompetent to ask. . . To write critically about critics thus becomes a way to reflect on the paradoxical effectiveness of a blinded vision that has to be rectified by means of insights that it unwittingly provides. (De Man, 1971: 106)

Smith, as the critic, is blind to the possibilities of Aboriginal art, but what he writes about European vision could well be adapted to renegotiating the relationship between Aboriginal art and Australian art history. His great insight lies in recognizing that aesthetic conventions shape perception; it is only a small step further to apply this logic to the reception of Aboriginal art. In terms of theorizing this perception, it is less beneficial to make distinctions between types of art, $\grave{a}$ la Brook and Smith, than to consider different understandings of Aboriginal art shaped by the views of particular periods.

Smith's work will remain an important record of the state of Australian art criticism and art history during the 20th century; it would be even better if we could look back on it and reflect upon how much attitudes have changed in relation the study of Aboriginal art. Regardless of how successful we have been in removing stigma and lessening divisions, Smith reminds us that 'conceptions developed retrospectively by historians and others, such as primitivism, exoticism and orientalism, invaluable as they are in drawing attention to long-term trends, are not used as substitutes for understanding the infinite complexity and subtlety of historical change' (Smith, 1992: 39, emphasis in original). We cannot get around 'doing the work' of art history in relation to Aboriginal art; neither can art historians continue to marginalize or ignore Aboriginal art, as excuses for this ignorance will no longer wash.

\section{Notes}

1. This award was previously known as the Ruth Adeney Koori Award. It is named in honour of Bernard Smith's late wife.

2. For example, in 1940, Berlin born anthropologist Leonhard Adam published Primitive Art. In 1943, the National Gallery and National Museum of Victoria held the 'Primitive Art Exhibition'. However, Art of the Australian Aboriginal by journalist Charles Barrett and publisher Robert Henderson Croll, also published in 1943, is much less definitive in its description of Indigenous Australians as 'primitive'.

3. Smith revises his opinion on the influence of Aboriginal art on Australian art, later citing it as an example of cultural convergence (Smith, 1988: 291, 299). 


\section{References}

Allen, Christopher (1997) Art in Australia: From Colonization to Postmodernism. London: Thames and Hudson.

Beilharz, Peter (1997) Imagining the Antipodes: Culture, Theory and the Visual in the Work of Bernard Smith. Cambridge: Cambridge University Press.

Brook, Donald (1998) 'Art, Craft, Kant, Racism', Meanjin 47(2): 165-170.

Burn, Ian et al. (1988) The necessity of Australian Art: An Essay About Interpretation. Sydney: Power Publications.

Butler, Rex (2002) A Secret History of Australian Art. St. Leonards: Craftman House Fine Art Publishing.

De Man, Paul (1971) Blindness \& Insight: Essays in the rhetoric of contemporary criticism. New York: Oxford University Press.

Gleeson, James (1971) Australian Painters, 3 vols. Sydney: Lansdowne Press.

Kleinert, Sylvia (1992) 'The Critical Reaction to the Hermannsburg School', in Jane Hardy, J. V. S. Megaw and Ruth Megaw (eds) The Heritage of Namatjira, pp. 217-48. Victoria: William Heinemann Australia.

Lehmann, Geoffrey (1977) Australian Primitive Painters. St Lucia: University of Queensland Press. Moore, William (1934) The Story of Australian Art, 2 vols. Sydney: Angus and Robertson.

Osbourne, H. (ed.) (1970) Oxford Companion to Art. Oxford: Oxford University Press.

Sayers, Andrew (2001) Australian Art. Oxford: Oxford University Press.

Smith, Bernard (1945) Place, Taste and Tradition: A Study of Australian Art since 1788. Sydney: Ure Smith.

Smith, Bernard (1960) European Vision and the South Pacific. Oxford: Clarendon Press.

Smith, Bernard (1962) Australian Painting, 1788-1960. London: Oxford University Press.

Smith, Bernard (1976) The Antipodean Manifesto: Essays in Art and History. Melbourne: Oxford University Press.

Smith, Bernard (1981) The Spectre of Truganini, 1980 Boyer Lectures. Sydney: Australian Broadcasting Commission.

Smith, Bernard (1988) The Death of the Artist as Hero: Essays in History and Culture Melbourne: Oxford University Press.

Smith, Bernard (1991) 'How Art Should Be Taught', Australian Society, Oct: 38-9.

Smith, Bernard (1992) Imagining the Pacific: In the Wake of Cook's Voyages. Melbourne: Melbourne University Press.

Smith, Bernard (2000) The Writings of Bernard Smith: Bibliography 1938-1998. Sydney: Power Publications.

Smith, Bernard (2001a) Australian Painting, 1788-2000 with additional chapters by Terry Smith and Christopher Heathcote. Melbourne: Oxford University Press.

Smith, Bernard (2001b) Private correspondence, n.p.

Smith, Terry (2002) Transformations in Australian Art, 2 vols. St Leonards: Craftman House. Spencer, John and Peter Wright (2000) 'Editors' Introduction', in Bernard Smith The Writings of Bernard Smith: Bibliography 1938-1998. Sydney: Power Publications. 


\section{University Library}

\section{- M M I N E R VA A gateway to Melbourne's research publications}

Minerva Access is the Institutional Repository of The University of Melbourne

Author/s:

LOWISH, SUSAN

Title:

European vision and Aboriginal art: blindness and insight in the work of Bernard Smith

Date:

2005

Citation:

Lowish, S. (2005). European vision and Aboriginal art: blindness and insight in the work of Bernard Smith. Thesis Eleven, 82(1), 62-72.

Publication Status:

Published

Persistent Link:

http://hdl.handle.net/11343/34625 